\title{
Nematodes in Hoplerytrinus unitaeniatus, Hoplias malabaricus and Pygocentrus nattereri (pisces characiformes) in Marajó Island, Brazil
}

\author{
Nematóides em Hoplerytrinus unitaeniatus, Hoplias malabaricus e Pygocentrus nattereri \\ (pisces characiformes) na Ilha de Marajó, Brasil
}

Raimundo Nonato Moraes Benigno ${ }^{1 *}$; Sérgio Carmona de São Clemente²; Edilson Rodrigues Matos Roberto Magalhães Pinto ${ }^{4}$; Delir Corrêa Gomes ${ }^{4}$; Marcelo Knoff ${ }^{4}$

${ }^{1}$ Laboratório de Parasitologia Animal, Universidade Federal Rural da Amazônia - UFRA, Belém, PA, Brasil

${ }^{2}$ Laboratório de Inspeção e Tecnologia de Pescado, Faculdade de Veterinária, Universidade Federal Fluminense - UFF, Niterói, RJ, Brasil

${ }^{3}$ Laboratório de Pesquisa Carlos Azevedo, Universidade Federal Rural da Amazônia - UFRA, Belém, PA, Brasil

${ }^{4}$ Laboratório de Helmintos Parasitos de Vertebrados, Instituto Oswaldo Cruz - IOC, Rio de Janeiro, RJ, Brasil

Received July 4, 2011

Accepted October 6, 2011

\begin{abstract}
The aim of this study was to evaluate the tegument, musculature and mesentery of 102 specimens of Hoplerytrinus unitaeniatus, 104 of Hoplias malabaricus and 101 of Pygocentrus nattereri, from Arari Lake, Marajó Island, State of Pará, Brazil. Were identified the nematodes Contracaecum sp., Eustrongylides sp. and Procamallanus sp. Contracaecum sp. was the most prevalent, with rates of $84.31 \%$ (H. unitaeniatus), $95.19 \%$ (H. malabaricus), and 89.11\% (P. nattereri). The highest prevalences of Eustrongylides sp. occurred in H. unitaeniatus (56.86\%) and H. malabaricus (53.84\%). Procamallanus sp. was only collected in the mesentery. Specimens of Eustrongylides sp. collected from the musculature were $91.9 \%$ of its population. Among the nematodes found in the mesentery, $98.34 \%$ were Contracaecum sp. with a mean intensity (MI) of $7.92 \pm 8.11$ (H. unitaeniatus), $8.49 \pm 8.34$ (H. malabaricus) and $7 \pm 6.40$ (P. nattereri). Contracaecum sp. presented the highest MI $(8.49 \pm 8.34)$ and mean abundance $(8.09 \pm 8.34)$. The highest MI values were observed in the mesentery. Eustrongylides sp. presented MI of $2.65 \pm 3.21$ (H. unitaeniatus), $3.41 \pm 3.27$ (H. malabaricus) and $2.17 \pm 1.18$ ( $P$. nattereri). Nematodes with zoonotic potential that were found with high prevalence, shows the importance of actions by the health authorities.
\end{abstract}

Keywords: Nematoda, Fish, hygienic-sanitary importance, Marajó Island, Brazil.

\section{Resumo}

Examinou-se o tegumento, mesentério e musculatura de 102 espécimes de Hoplerytrinus unitaeniatus, 104 de Hoplias malabaricus e 101 de Pygocentrus nattereri, do Lago Arari, Ilha do Marajó, Estado do Pará, Brasil. Foram identificados os nematóides Contracaecum sp., Eustrongylides sp. e Procamallanus sp. nas três espécies de peixes. Contracaecum sp. foi o mais prevalente, com índices de 84,31\% (H. unitaeniatus), 95,19\% (H. malabaricus) e 89,11\% (P. nattereri). As maiores prevalências de Eustrongylides sp. foram observadas em H. unitaeniatus (56,86\%) e H. malabaricus (53,84\%). Procamallanus sp. só foi coletado no mesentério, sendo o sítio de infecção mais parasitado. Na musculatura, foram coletados espécimes de Eustrongylides sp., representando 91,9\% de sua populaçáo. Dos nematóides coletados no mesentério, 98,34\% foram Contracaecum sp. com intensidade média (IM) de 7,92 $\pm 8,11$ (H. unitaeniatus), 8,49 $\pm 8,34$ (H. malabaricus) e 7,0 $\pm 6,40$ (P. nattereri). Contracaecum sp. apresentou maior IM $(8,49 \pm 8,34)$ e abundância média $(8,09 \pm 8,34)$. Os maiores valores de IM foram obtidos no mesentério. Eustrongylides sp. apresentou IM de 2,65 $\pm 3,21$ (H. unitaeniatus), 3,41 $\pm 3,27$ (H. malabaricus) e 2,17 $\pm 1,18$ (P. nattereri). Nematóides com potencial zoonótico, encontrados com alta prevalência, demonstram a importância para açóes das autoridades sanitárias.

Palavras-chave: Nematoda, peixes, importância higiênico-sanitária, Ilha de Marajó, Brasil.

\footnotetext{
${ }^{*}$ Corresponding author: Raimundo Nonato Moraes Benigno

Laboratório de Parasitologia Animal, Universidade Federal Rural da

Amazônia - UFRA, Av. Presidente Tancredo Neves, 2501, CEP 66077-530,

Belém, PA, Brasil

e-mail: raimundo.benigno@gmail.com
} 
The increasing popular interest in consuming raw or poorly cooked fish has induced sanitary authorities and researchers to pay more attention to this trend, taking into account that it has already been well established that bioagents with zoonotic potential exist in different aquatic environments. According to Souza (2003), such agents can promote alterations in fish production, with a strong impact on the safety and quality of the fish.

Fish can be contaminated with parasites that may be potentially harmful to humans. According to González et al. (2001), the pathogens can be classified into two groups: firstly, parasites of public health interest that may be harmful to consumers; and secondly, agents that only affect fish by inducing lesions in the hosts and thus altering their commercial value. Such lesions may even, based on sanitary and hygiene standards, lead to rejection of these fish because of the ensuing repugnant appearance of the flesh.

Most occurrences of parasites of public health interest are related to consumption of raw, poorly cooked, inadequately salted and cold-smoked fish. Human cases of parasitism by helminths due to consumption of fish processed under these conditions have been reported in Brazil and are associated with the species Ascocotyle (Phagicola) longa (Ransom, 1920) (CHIEFFI et al., 1990, 1992; ALMEIDA-DIAS; WOICIECHOVSKI, 1994), Diphyllobothrium latum (Linnaeus, 1758) (EDUARDO et al., 2005a, b; SANTOS; FARO, 2005; TAVARES et al., 2005; EMMEL et al. 2006; LACERDA et al., 2007; CAPUANO et al., 2007; LLAGUNO et al., 2008), Clonorchis sinensis (Cobbold, 1875) (LEITE et al., 1989; DIAS et al., 1992) and Gnathostoma sp. (DANI et al., 2009).

Among the nematodes of zoonotic potential, anisakids are prominent and, although no human cases have yet been recorded in Brazil, they have already been reported in marine and freshwater fish (PADOVANI et al., 2005). Human anisakiasis is considered to be the most severe infection caused by consumption of contaminated fish harboring third-stage larvae of nematodes of the genera Anisakis (Dujardin, 1845), Pseudoterranova (Mozgovoy, 1950) and Contracaecum (Railliet \& Henry, 1912). Infections with the species A. simplex (Rudolphi, 1809) and P. decipiens (Krabbe, 1878) are the most important occurrences, according to Ishikura et al. (1993) and Adams et al. (1997). Contracaecum larvae mostly occur in the visceral organs and mesentery of fish, thus limiting their zoonotic threat, which may explain why human cases are rare even considering that mammals are susceptible to experimental infection with these larvae (VIDAL-MARTINEZ et al. 1994; BARROS et al., 2004).

Another nematode group with zoonotic potential is Dioctophymatidae, represented by larvae of the genera Dioctophyma (Collet-Meygret, 1802), Eustrongylides (Jäegerskiold, 1909) and Hystrichis (Dujardin, 1845), which can infect freshwater fish. These fish are essential hosts only in the life cycle of eustrongylids, considering that the third-stage larvae of this parasite develop into the fourth stage in fish on which piscivorous birds feed to complete the cycle. Moreover, predatory fish can act as paratenic hosts by ingesting other infected fish with fourth-stage larvae (COLE, 1999). Cases of accidental human infection can occur if raw or poorly cooked fish is consumed, and there have been further reports of symptoms associated with the abdominal location of the nematodes (EBERHARD et al., 1989; SCHANTZ, 1989; WITTNER et al., 1989; NARR et al., 1996).

The data available from the Amazon region on the parasitic biota of economically important fish species are very limited, and there is a lack of information about parasites of zoonotic potential. The aim of the present study was to analyze the parasitic profile of nematodes with hygiene and sanitary relevance that infect fish of commercial value, caught in the Ararí Lake, Marajó Island, State of Pará, Brazil.

Between August and December 2009, 102 specimens of gold wolf fish, Hoplerytrinus unitaeniatus (Spix \& Agassiz, 1829), of weight 107-376 g and standard length $15.4-25 \mathrm{~cm}, 104$ specimens of thraira, Hoplias malabaricus (Bloch, 1794), of weight 110-530 g and standard length $17.8-27.2 \mathrm{~cm}$ and 101 specimens of red-bellied piranha, Pygocentrus nattereri (Kner, 1858), of weight 111-276 g and standard length $12.5-16.5 \mathrm{~cm}$ were randomly purchased from fishermen, at the time of anchorage, in Ararí Lake, municipality of Santa Cruz do Arari, Marajó Island, State of Pará, Brazil (0³9' 48” S 4910'30" W).

The fish specimens were kept in insulated containers with ice and were processed in the Animal Parasitology Laboratory, Federal Rural University of the Amazon, Belém campus, State of Pará. The tegmental surface of the fish was firstly inspected and their sex was determined. To recover visceral parasites, the specimens were gutted and the organs and abdominal musculature were transferred to individual Petri dishes with $0.65 \% \mathrm{NaCl}$ solution to be examined under a stereoscopic microscope. The filleted flesh, which was obtained by means of an incision from near the opercula to the insertion of the caudal fin, was observed on a candling table for better evaluation and recovery of tissue parasites. The larvae and adults were processed in accordance with the methodology of Amato et al. (1991) and Eiras et al. (2006). The nematodes were identified based on Hartwich (1974), Moravec (1994) and Vicente and Pinto (1999).

Prevalence, mean intensity, range of infection and mean abundance were obtained in accordance with Bush et al. (1997). To compare the prevalences of nematodes in different hosts and at different infection sites, the chi-square test was applied. Linear associations between infection intensity and variables relating to weight and total length were evaluated by means of Pearson's linear correlation coefficient. Considering that the intensity and mean abundance of infection did not present Gaussian distribution, Kruskal-Wallis analysis of variance was applied with Tukey post-test analysis, as recommended by Ayres et al. (2007), for comparing mean intensity and mean abundance of parasitism, in relation to the nematode species and infection sites. Alpha $=0.05$ was the level preset for rejection of the null hypothesis. The statistical procedures were performed using the BioEstat 5 software.

Representative specimens from each nematode species were deposited in the Helminthological Collection of the Oswaldo Cruz Institute (CHIOC), Rio de Janeiro, State of Rio de Janeiro, Brazil.

From the three fish species collected (H. unitaeniatus, $H$. malabaricus and $P$. nattereri), 2,578 nematodes belonging to three species were obtained: Contracaecum sp. $(2,152)$, Eustrongylides sp. (395) and Procamallanus sp. (31). H. malabaricus was the most infected fish species, with 1037 worms, following by H. unitaeniatus and $P$. nattereri with respectively 839 and 702 worms. 
The data indicated that in the three fish species examined, larvae of Contracaecum sp. and Eustrongylides sp. and adults of Procamallanus sp. appeared with patterns of either single or concomitant infections, except for Procamallanus sp. in the samples of $H$. unitaeniatus and $H$. malabaricus (Table 1 ).

Parasitism occurred at high prevalence rates in the three fish species: greater than 92\% overall; and reaching $96.15 \%$ in the specimens of $H$. malabaricus. Contracaecum sp. was the most prevalent parasite genus, since $84.29 \%$ of the specimens of $H$. unitaeniatus, $95.19 \%$ of $H$. malabaricus and $89.11 \%$ of $P$. nattereri were infected with these parasites, whereas representatives of Procamallanus sp. appeared at the lowest rates: $3.9 \%, 1.92 \%$ and $10.89 \%$ respectively, in the three fish species considered. The highest infection rates relating to Eustrongylides sp. were $56.86 \%$ in $H$. unitaeniatus and $53.84 \%$ in $H$. malabaricus. Analysis on the parameters referring to single and associated infections revealed that the rate for Contracaecum sp. was significantly higher $(58.42 \%)$ in $P$. nattereri. The rates in $H$. unitaeniatus and $H$. malabaricus were similar to what was observed in co-infections with Eustrongylides sp. $(\mathrm{p}<0.05)$ (Table 1).

Parasitism occurred at five infection sites (musculature, mesentery and serosa of the stomach, kidneys and ovaries), singly or concomitantly. The musculature only showed specimens of Eustrongylides sp., while Procamallanus sp. only occurred in the mesentery. This site had the highest frequencies of nematodes:
$78.74 \%$ in $H$. unitaeniatus, $81.77 \%$ in $H$. malabaricus and 92.17 in $P$. nattereri (Table 2). Correlations between weight, total length and intensity of infection were significant only in specimens of H. malabaricus ( $\mathrm{p}=0.0003)$.

Significantly, Contracaecum sp. appeared with higher mean infection (MI) and mean abundance (MA) rates: respectively, $8.49 \pm 8.34$ and $8.09 \pm 8.34$, obtained in $H$. malabaricus. However, these were not statistically different from those observed in H. unitaeniatus and P. nattereri ( $\mathrm{p}>0.05)$ (Table 2). Regarding the infection sites, the highest MI values were observed in the mesentery, irrespective of the host. There was greater intensity of infection in fish parasitized with Contracaecum sp., with higher values for samples recovered from $H$. malabaricus ( $8.41 \pm 8.35$; 841 worms). However, these values were not statistically different from those obtained in the other hosts $(\mathrm{p}>0.05)$ : respectively $7.65 \pm 8.05$ (658 worms) and $6.91 \pm 6.34$ (622 worms) from $H$. unitaeniatus and $P$. nattereri.

The MI values for Eustrongylides sp. in the musculature, i.e. the site with highest prevalence of parasitism (91.9\% or 363 out of the 395 specimens collected from the fish examined), were $2.43 \pm 3.11$ in $H$. unitaeniatus, $3.38 \pm 3.14$ in $H$. malabaricus and $2.19 \pm 1.15$ in $P$. nattereri, and these did not differ significantly ( $p>0.05$ ).

The high prevalence of nematodes of hygiene and sanitary interest in these three species of commercially important fish has been correlated with the high infective capacity of Contracaecum sp. and

Table 1. Prevalences (\%) of the nematodes Contracaecum sp., Eustrongylides sp. and Procamallanus sp. recovered from specimens of the fish species $H$. unitaeniatus, $H$. malabaricus and P. nattereri that were caught from Arari Lake, Marajó Island, State of Pará, Brazil, between August and December 2009.

\begin{tabular}{|c|c|c|c|c|c|c|}
\hline \multirow{2}{*}{$\begin{array}{c}\text { Fish species } \\
\text { Nematodes }\end{array}$} & \multicolumn{2}{|c|}{ H. unitaeniatus } & \multicolumn{2}{|c|}{ H. malabaricus } & \multicolumn{2}{|c|}{ P. nattereri } \\
\hline & Infecteds & $\%$ & Infecteds & $\%$ & Infecteds & $\%$ \\
\hline Contracaecum sp. (C) & 35 & 34.31 & 43 & 41.35 & 59 & $58.42^{*}$ \\
\hline Eustrongylides sp. (E) & 8 & 7.84 & 1 & 0.96 & 1 & 0.99 \\
\hline Procamallanus sp. (P) & - & - & - & - & 2 & 1.98 \\
\hline Single infections & 43 & 42.15 & 44 & 42.31 & 62 & 61.39 \\
\hline$C+E$ & 47 & 46.08 & 54 & 51.92 & 22 & 21.78 \\
\hline $\mathrm{C}+\mathrm{P}$ & 1 & 0.98 & 1 & 0.96 & 9 & 8.91 \\
\hline$C+E+P$ & 3 & 2.94 & 1 & 0.96 & - & - \\
\hline Concomitant infections & 51 & 50 & 56 & 53.84 & 31 & 30.69 \\
\hline Total of infections & 94 & 92.15 & 100 & 96.15 & 93 & 92.08 \\
\hline
\end{tabular}

*Showing a significant difference $(\mathrm{p}<0.05)$

Table 2. Prevalence (P), mean intensity (MI), range of infection (RI), mean abundance (MA), site of infection (SI) and CHIOC deposit numbers of the nematodes Contracaecum sp., Eustrongylides sp. and Procamallanus sp. recovered from the fish species Hoplerytrinus unitaeniatus $(\mathrm{Hu})$, Hoplias malabaricus $(\mathrm{Hm})$ and Pygocentrus nattereri $(\mathrm{Pn})$ that were captured in Arari Lake, Marajó Island, State of Pará, Brazil, between August and December of 2009.

\begin{tabular}{|c|c|c|c|c|c|c|c|c|c|}
\hline \multirow{2}{*}{$\begin{array}{c}\text { Nematode } \\
\text { species }\end{array}$} & \multicolumn{3}{|c|}{ Contracaecum sp. } & \multicolumn{3}{|c|}{ Eustrongylides sp. } & \multicolumn{3}{|c|}{ Procamallanus sp. } \\
\hline & $H u$ & $\mathrm{Hm}$ & $P n$ & $H u$ & $\mathrm{Hm}$ & $P n$ & $H u$ & $\mathrm{Hm}$ & $P n$ \\
\hline $\mathrm{P}(\%)$ & 84.31 & 95.19 & 89.11 & 56.86 & 53.85 & 22.74 & 3.92 & 1.92 & 10.89 \\
\hline MI & $7.92 \pm 8.11$ & $8.49 \pm 8.34$ & $7 \pm 6.40$ & $2.65 \pm 3.21$ & $3.41 \pm 3.27$ & $2.17 \pm 1.18$ & $1 \pm 0.20$ & $2.5 \pm 0.40$ & $2 \pm 0.73$ \\
\hline RI & $1-50$ & $1-44$ & $1-41$ & $1-26$ & $1-20$ & $1-8$ & - & $1-4$ & $1-4$ \\
\hline MA & $6.68 \pm 8.11$ & $8.09 \pm 8.34$ & $6.24 \pm 6.40$ & $1.51 \pm 3.21$ & $1.84 \pm 3.27$ & $0.50 \pm 1.18$ & $0.04 \pm 0.20$ & $0.05 \pm 0.40$ & $0.22 \pm 0.73$ \\
\hline SI & me, sl, so, ss & me, sl, ss & me, sl, ss & $\mathrm{me}, \mathrm{ss}, \mathrm{mu}$ & me, sl, mu & me, ss, mu & me & me & me \\
\hline CHIOC & 35759 & 35760 & 35761 & 35762 & 35763 & 35764 & 35765 & 35766 & 35767 \\
\hline
\end{tabular}

$\mathrm{me}=$ mesentery, $\mathrm{mu}=$ musculature, $\mathrm{sl}=$ serosa of liver, $\mathrm{so}=$ serosa of ovaries, $\mathrm{ss}=$ serosa of stomach. 
Eustrongylides sp., considering that findings of adult Procamallanus sp. in the mesentery are uncommon, since the adults of these nematodes parasitize the stomach and intestine of freshwater and marine fish (MORAVEC et al., 2000). The three fish species captured in Arari Lake, which is located in the eastern hydrographic basin and is considered to be the largest depression on Marajó Island, were highly susceptible to infection, with heavy parasitism due to nematodes of the genera Contracaecum sp. and Eustrongylides sp.

The data indicate that in the case of Contracaecum sp., crustaceans and piscivorous birds are also implicated in the food chain in this aquatic environment, the former acting as intermediate hosts and the latter as the definitive hosts. Fish can act as the second intermediate hosts by feeding on parasitized crustaceans or on paratenic hosts, in the case of predatory fish. In both cases, fish may be a source of infection for piscivorous birds and marine mammals (KOIE; FAGERHOLM, 1995; KOIE et al., 1995; ANDERSON, 2000). In parasitism involving Eustrongylides sp., the definitive hosts are piscivorous birds; while in infections with Contracaecum sp., fish participate as the second intermediate hosts and contamination occurs after ingestion of parasitized oligochaetes (COLE, 1999; COYNER et al., 2001).

Brazilian data (KOHN et al., 1988; MARTINS et al. 2003, 2005, 2009; MADI; SILVA, 2005; BARROS et al., 2006, 2007, 2010; PARAGUASSÚ; LUQUE, 2007; VICENTIN, 2009; RODRIGUES, 2010) show that to date, most investigations dealing with parasites of hygiene and sanitary importance in H. unitaeniatus, $H$. malabaricus or $P$. nattereri have been conducted on specimens caught in aquatic environments of the Brazilian Amazon region. The only other investigations have been the studies by Martins et al. (2005) dealing with $H$. unitaeniatus and $H$. malabaricus from the swamplands of the State of Maranhão; Barros et al. (2006) with P. nattereri from the metropolitan area of Cuiabá, State of Mato Grosso (MT); Barros et al. (2007) with H. malabaricus from the municipality of Santo Antonio do Leverger, MT; and Barros et al. (2010) with $P$. nattereri in the Cuiabá river, municipality of Barão de Melgaço, MT. The most compatible previous data for comparisons with our findings are from Martins et al. (2005), who recovered samples of Contracaecum sp. from $80 \%$ of the specimens of $H$. unitaeniatus and from $100 \%$ of $H$. malabaricus.

Concerning $H$. malabaricus, other reports in Brazil also add data relating to the high infectivity of specimens of Contracaecum sp. in this fish species (KOHN et al., 1988; MADI; SILVA, 2005; MARTINS et al., 2005; PARAGUASSÚ; LUQUE, 2007). Taking into account the parasitism with Eustrongylides sp., only the lowest rate (58\%) observed by Martins et al. (2005) is close to what was obtained in the present study. Lower rates were also detected in the State of Rio Grande do Sul by Rodrigues (2010) (32\%), and in the State of São Paulo by Martins et al. (2003) (31.69\%).

The fact that the highest parasite prevalence and intensities occurred in the mesentery of the three fish species, thus reflecting the significantly high mean intensity, was directly related to the marked tropism of Contracaecum sp. larvae, which accounted for $98.34 \%$ of the nematode specimens at this site. This characteristic behavior was also documented by Barros et al. (2010) in specimens of $P$. nattereri infected with Contracaecum sp. larvae, which presented 99\% prevalence. Moreover, absence of these larvae in the musculature of $P$. nattereri has already been reported by
Barros et al. (2006), Vicentin (2009) and Barros et al. (2010) and in $H$. malabaricus by Barros et al. (2007) and Rodrigues (2010). Nevertheless, occurrences of Contracaecum sp. larvae in the musculature of Hoplias malabaricus were observed in Brazil by Martins et al. (2003) in the State of São Paulo and Martins et al. (2005) in the State of Maranhão, and also in Colombia by Olivero-Verbel et al. (2006) and Pardo et al. (2008).

The marked tropism of Eustrongylides sp. larvae towards the musculature confirms data from Barros et al. (2010) relating to specimens of $P$. nattereri in which the larvae presented $82.6 \%$ prevalence. However, Vicentin (2009) did not observe tropism of Eustrongylides sp. towards the musculature in 152 specimens of $P$. nattereri.

In the present investigation, the mean intensity of Contracaecum sp. in $H$. malabaricus was lower than the values reported in Brazil by Martins et al. (2003) (11.24), Madi and Silva (2005) (15.56) and Martins et al. (2005) (24.6); and in Colombia by Olivero-Verbel (2006) (77.82) in specimens captured in the northern coast and Pardo et al. (2008) (52.6). Nevertheless, the mean intensities of infection reported in Colombia (1.0) by Olivero-Verbel (2006) in Amazonian fish and in Brazil (2.8) by Rodrigues (2010) were lower. Considering specimens of $P$. nattereri, parasitism with Contracaecum sp. occurred at higher intensity in the fish examined by Vicentin (2009) and Barros et al. (2010), with mean intensities of 5.75 and 1.04 , respectively.

The present data show that the mean intensity of Eustrongylides sp. in H. malabaricus was closer to 3.93 (MARTINS et al., 2009) and greater than what was previously reported (1.0) by Rodrigues (2010); in P. nattereri, it was closer to 2.54 (BARROS et al., 2010), and also greater than what was previously reported (1.0) by Vicentin (2009).

The variables of weight and length were also observed to influence the intensity of infection occurring in specimens of $H$. malabaricus, by Madi and Silva (2005) and Olivero-Verbel et al. (2006). In addition, a positive correlation between the prevalence of parasitism and the weight (600-750 g) of specimens of $H$. malabaricus was detected in the study by Martins et al. (2003). To explain this fact relating to parasitism by Contracaecum sp., Madi and Silva (2005) suggested that bigger fish accumulate greater quantities of larvae, since they frequently feed on smaller parasitized specimens and mostly escape from predation by the definitive hosts of these nematodes. The data obtained from this first investigation on specimens of piscivorous fish caught in Arari Lake confirm the role that these fish play in the life cycle of nematodes of public health interest, with high prevalence of the parasites. This may be useful for the sanitary authorities, especially those of the riverfront municipalities on Marajó Island, given that people living in these communities are, historically, the main consumers of the three fish species investigated here.

\section{References}

Anderson RC. Nematode Parasites of Vertebrates: Their Development and Transmission. 2nd ed. London: CAB Publishing; 2000. 672 p. http:// dx.doi.org/10.1079/9780851994215.0000

Adams AM, Murrell KD, Cross JH. Parasites of fish and risks to public health. Rev Sci Tech Off Int Epiz 1997; 16(2): 652-660. 
Almeida-Dias ER, Woiciechovski E. Ocorrência da Phagicola longa (Trematoda: Heterophyidae) em mugilídeos e no homem, em Registro e Cananéia, SP. Hig Aliment 1994; 8(31): 43-46.

Amato JFR, Boeger WA, Amato SB. Protocolos para laboratório-Coleta e processamento de parasitos de pescado. Seropédica: Imprensa Universitária UFRRJ; $1991.81 \mathrm{p}$.

Ayres M, Ayres DL, Santos AAS. BioEstat 5: aplicaçōes estatísticas nas áreas das Ciências Biológicas e Médicas. 5. ed. Belém: Publicaçôes Avulsas do Mamirauá; 2007.361 p. Available from: http://www.mamiraua.org. br/downloads/programas.

Barros LA, Tortelly R, Pinto RM, Gomes DC. Effects of experimental infections with larvae of Eustrongylides ignotus Jäegerskiold, 1909 and Contracaecum multipapillatum (Drasche, 1882) Baylis, 1920 in rabbits. Arq Bras Med Vet Zootec 2004; 56(3): 325-332. http://dx.doi. org/10.1590/S0102-09352004000300007

Barros LA, Moraes Filho J, Oliveira RL. Larvas de nematóides de importância zoonótica encontradas em traíras (Hoplias malabaricus bloch, 1794) no município de Santo Antonio do Leverger, MT. Arq Bras Med Vet Zootec 2007; 59(2): 533-535. http://dx.doi.org/10.1590/ S0102-09352007000200042

Barros LA, Moraes Filho J, Oliveira RL. Nematóides com potencial zoonótico em peixes com importância econômica provenientes do rio Cuiabá. Rev Bras Ci Vet 2006; 13(1): 55-57.

Barros LA, Mateus LAF, Braum DT, Bonaldo J. Aspectos ecológicos de endoparasitos de piranha vermelha (Pygocentrus nattereri, Kner, 1860) proveniente do rio Cuiabá. Arq Bras Med Vet Zootec 2010; 62(1): 228-231. http://dx.doi.org/10.1590/S0102-09352010000100033

Bush AO, Lafferty KD, Lotz DM, Shostak AW. Parasitology meets Ecology on its own terms: Margolis et al. revisited. J Parasitol 1997; 83(4): 575-583. PMid:9267395. http://dx.doi.org/10.2307/3284227

Capuano DM, Okino MHT, Mattos HRM, Vieira Torres DMAG. Difilobotríase: Relato de caso no município de Ribeirão Preto, SP, Brasil. RBAC 2007; 39(3): 163-164.

Chieffi PP, Leite OH, Dias RMDS, Vieira Torres DMA, Mangini ACS. Human parasitism by Phagicola sp. (Trematoda- Heterophyidae) in Cananéia, São Paulo State, Brazil. Rev Inst Med Trop São Paulo 1990; 32(4): 285-288. PMid:2101522.

Chieffi PP, Gorla MC, Vieira Torres DMA, Dias RMDS, Mangini ACS, Monteiro AV, et al. Human infection by Phagicola sp. (TrematodaHeterophyidae) in the municipality of Registro, São Paulo State, Brazil. J Trop Med Hyg 1992; 95(5): 346-348. PMid:1404559.

Cole RA. Eustrongylidosis. In: Friend M, Franson JC. Field Manual of Wildlife Diseases: general field procedures and diseases of birds. Washington: Biological Resources Division, Information and Technology Report; 1999. p. 223-228. Section, n. 5. [cited 2011 Jan. 03]. Available from: www.nwhc.usgs.gov/publications/field_manual.

Coyner DF, Schaack SR, Spalding MG, Forrester DJ. Altered predation susceptibility of mosquitofish infected with Eustrongylides ignotus.J Wildl Dis 2001; 37(3): 556-560. PMid:11504229.

Dani CMC, Sanchotene PV, Mais CPA, Mota KF, Piñero-Maceira J. Gnatostomíase no Brasil - Relato de caso. An Bras Dermatol 2009; 84(4): 400-404. PMid:19851673. http://dx.doi.org/10.1590/S036505962009000400012

Dias RMD,S Mangini ACS, Vieira Torres DMA, Vellosa SAG, Silva RM, Silva MIPG. Introdução de Clonorchis sinensis por imigrantes do leste asiático no Brasil e a suspensáo da obrigatoriedade de exames laboratoriais para obtenção de vistos de permanência. Rev Bras Anal Clin 1992; 24(2): 29-30.

Eberhard ML, Hurwitz H, Sun AM, Coletta D. Intestinal perforation caused by larval Eustrongylides (Nematoda: Dioctophymatoidae) in New Jersey. Am J Trop Med Hyg 1989; 40(6): 648-650. PMid:2742040.

Eduardo MBP, Sampaio JLM, Gonçalves EMN, Castilho VLP, Randi AP, Thiago C, et al. Diphyllobothrium spp.: um parasita emergente em São Paulo, associado ao consumo de peixe cru - sushis e sashimis, São Paulo, março de 2005. Bol Epidemiol Paulista 2005a; 2(15): 1-5.

Eduardo MBP, Sampaio JLM, Suzuki E, César MLVS, Gonçalves EMN, Castilho VLP, et al. Investigação epidemiológica do surto de Difilobotríase, São Paulo, maio de 2005. Bol Epidemiol Paulista 2005b; 2(17): 1-12.

Eiras JC, Takemoto RM, Pavanelli GC. Métodos de estudos e técnicas laboratoriais em parasitologia de peixes. 2. ed. Maringá: EDUEM; 2006. 199 p.

Emmel VE, Inamine E, Secchi C, Brodt TCZ, Amaro COM, Cantarelli VV, et al. Diphyllobothrium latum: relato de caso no Brasil. Rev Soc Bras Med Trop 2006; 39(1): 82-84. PMid:16501774. http://dx.doi. org/10.1590/S0037-86822006000100017

González I, Arias MTG, Hernández PE, Martín R. Aspectos higiénicosanitarios relacionados con la presencia de parásitos en los productos de la pesca. I. Parásitos de interés. Alimentaria 2001; 321: 55-60.

Hartwich G. Keys to genera of the Ascaridoidea. In: Anderson RC, Chabaud AG, Willmott S, editors. CIH keys to the nematode parasites of vertebrates. London: Farnham Royal; Commonwealth Agricultural Bureaux; 1974. n. 2, 15 p.

IshikuraH, Kikuchi K, Nagasawa K, Ooiwa T, Takamiya H, Sato N, et al. Anisakidae and anisakidosis. In: Sun, T. Prog Clin Parasitol. New York: Springer-Verlag; 1993. p. 43-102. PMid:8420604. http://dx.doi. org/10.1007/978-1-4612-2732-8_3

Koie M, Fagerholm HP. The life cycle of Contracaecum osculatum (Rudolphi, 1802) sensu stricto (Nematoda, Ascaridoidea, Anisakidae) in view of experimental infections. Parasitol Res 1995; 81(6): 481-489. http://dx.doi.org/10.1007/BF00931790

Koie M, Berland B, Burt MDB. Development to third-stage larvae occurs in the eggs of Anisakis simplex and Pseudotetranova decipiens (Nematoda, Ascaridoidea, Anisakidae). Can J Fish Aquatic Sci 1995; 52(S1): 134-139. http://dx.doi.org/10.1139/f95-519

Kohn A, Fernandes BMM, Pipolo HV, Godoy MP. Helmintos parasitos de peixes das Usinas Hidrelétricas da Eletrosul (Brasil). II. Reservatórios de Salto Osório e de Salto Santiago, Bacia do Rio Iguaçu. Mem Inst Oswaldo Cruz 1988; 83(3): 299-303. http://dx.doi.org/10.1590/S007402761988000300006

Lacerda JUV, Almeida Filho GG, Coutinho HDM. Ocorrência de difilobotríase na Paraíba não relacionada a viajantes. Rev Méd Ana Costa 2007; 12(3): 1-4.

Leite OHM, Higaki Y, Serpentini SLP, Carvalho AS, Amato Neto $\mathrm{V}$, Torres DMA, et al. Infecção por Clonorchis sinensis em imigrantes asiáticos no Brasil: tratamento com praziquantel. Rev Inst Med Trop São Paulo 1989; 31(6): 416-422. http://dx.doi.org/10.1590/S003646651989000600008

Llaguno MM, Cortez-Escalante J, Waikagul J, Faleiros ACG, Chagas F, Castro C. Diphyllobothrium latum infection in a non-endemic country: case report. Rev Soc Bras Med Trop 2008; 41(3): 301-303. PMid:18719813. http://dx.doi.org/10.1590/S0037-86822008000300015 
Madi RR, Silva MSR. Contracaecum Railliet \& Henry, 1912 (Nematoda, Anisakidae): o parasitismo relacionado à biologia de três espécies de peixes piscívoros no reservatório do Jaguari, SP. Rev Bras Zoociências 2005; 7(1): 15-24.

Martins ML, Santos RS, Takahashi HK, Marengoni NG, Fujimoto RY. Infection and susceptibility of three fish species from the Paraná River, Presidente Epitácio, SP, Brazil to Contracaecum sp. larvae (Nematoda: Anisakidae). Acta Scientiarum Ani Sci 2003; 25(1): 73-78.

Martins ML, Onaka EM, Fenerick Junior J. Larval Contracaecum sp. (Nematoda: Anisakidae) in Hoplias malabaricus and Hoplerythrinus unitaeniatus (Osteichthyes: Erythrinidae) of economic importance in occidental marshlands of Maranhão, Brazil. Vet Parasitol 2005; 127(1): 51-59. PMid:15619375. http://dx.doi.org/10.1016/j. vetpar.2004.09.026

Martins ML, Santos RS, Marengoni NG, Takahashi HK, Onaka EM. Seasonality of Eustrongylides sp. (Nematoda: Dioctophymatidae) larvae in fishes from Paraná river, south-western Brazil. Bol Inst Pesca 2009; 35(1): 29-37.

Moravec F. Parasitic nematodes of freshwater fishes of Europe. Dordrecht: Kluwer Academic Publishers; 1994. 473 p.

Moravec F, Salgado-Maldonado G, Caspeta-Mandujano, J. Three new Procamallanus (Spirocamallanus) species from freshwater fishes in Mexico. J Parasitol 2000; 86(1): 119-127. PMid:10701574.

Narr LL, O’Donnell JG, Libster B, Alessi P, Abraham D. Eustrongylidiasis - a parasitic infection acquired by eating live minnows. J Am Osteopath Assoc 1996; 96(7): 400-402. PMid:8758872.

Olivero-Verbel J, Baldiris-Avila R, Güette-Fernández J, Benevides-Alvarez A, Mercado-Camargo J, Arroyo-Salgado B. Contracaecum sp. infection in Hoplias malabaricus (moncholo) from rivers and marshes of Colombia. Vet Parasitol 2006; 140(1-2): 90-97. PMid:16650597. http://dx.doi. org/10.1016/j.vetpar.2006.03.014

Padovani RES, Knoff M, São Clemente SC, Mesquita EFM, Jesus EFO, Gomes DC. The effect of in vitro gamma radiation on Anisakis sp. larvae collected from the pink cusk-eel, Genypterus brasiliensis Regan, 1903. $R$ Bras Ci Vet 2005; 12(1-3): 137-141.
Pardo S, Zumaque A, Noble H, Mahecha HS. Contracaecum sp (Anisakidae) em el pez Hoplias malabaricus, capturado em la Ciénaga Grande de Lorica, Córdoba. Rev MVZ Córdoba 2008; 13(2): 1304-1314.

Paraguassú AR, Luque JL. Metazoários parasitos de seis espécies de peixes do reservatório de Lajes, estado do Rio de Janeiro, Brasil. Rev Bras Parasitol Vet 2007; 16(3): 121-128. http://dx.doi.org/10.1590/ S1984-29612007000300002

Rodrigues AP. Helmintos parasitos de Hoplias malabaricus (Ostheichtyes: Erytrinidae) comercializados na região sul do Rio Grande do Sul [Dissertação]. Pelotas: Universidade Federal de Pelotas; 2010.

Santos FLN, Faro LB. The first confirmed case of Diphyllobothrium latum in Brazil. Mem Inst Oswaldo Cruz 2005; 100(6): 585-586. http://dx.doi. org/10.1590/S0074-02762005000600013

Schantz PM. The Dangers of Eating Raw Fish. N Engl J Med 1989; 320(17): 1143-1145. PMid:2710177. http://dx.doi.org/10.1056/ NEJM198904273201711

Souza ATS. Certificação da qualidade de pescados. Biológico 2003; 65(1-2): 11-13.

Tavares LER, Luque JL, Bonfim TCB. Human diphyllobothriasis: reports from Rio de Janeiro, Brazil. Rev Bras Parasitol Vet 2005; 14(2): 85-87. PMid:16153350.

Vicente JJ, Pinto RM. Nematóides do Brasil: Nematóides de peixes. Atualização: 1985-1998. Rev Bras Zool 1999; 16(3): 561-610.

Vicentin W. Composiçâo e estrutura das infracomunidades de metazoários endoparasitos de Pygocentrus nattereri (Kner, 1858) e Serrasalmus marginatus (Valenciennes, 1837) (Characiformes-Serrasalminae), espécies simpátricas no rio Negro, Pantanal, Brasil [Dissertação]. Campo Grande: Universidade Federal do Mato Grosso do Sul; 2009.

Vidal-Martinez VM, Osório-Saraia D, Overstreet RM. Experimental infection of Contracaecum multipapillatum (Nematoda:Anisakinae) from Mexico in domestic cat. J Parasitol 1994; 80(4): 576-579. http://dx.doi. org/10.2307/3283194

Wittner M, Turner JW, Jacquette G, Ash LR, Salgo MP, Tanowitz HB. Eustrongylidiasis - a parasitic infection acquired by eating sushi. $N$ Engl J Med 1989; 320(17): 1124-1126. PMid:2710174. http://dx.doi. org/10.1056/NEJM198904273201706 